\title{
Allelopathic potential of Crysopogon zizanioides (L.) and Paspalum millegrana (Schrad) on the germination of lettuce ${ }^{1}$
}

\section{Erica Cardoso Costa ${ }^{2}$ (D) Francisco Sandro Rodrigues Holanda ${ }^{2, *}$ (D), Eliana Midori Sussuchi ${ }^{3}$ (D), Lucas Santos Bomfim ${ }^{3}$ (D), Renisson Neponuceno de Araújo Filho ${ }^{4}$}

\author{
'Parte da dissertação do primeiro autor, Programa de Pós-graduação em Agricultura e Biodiversidade \\ Universidade Federal de Sergipe, Brasil. \\ 2Universidade Federal de Sergipe, Departamento de Engenharia Agronômica, campus São Cristovão. \\ Av. Marechal Rondon, s/n, CEP 49100-000, São Cristóvão, SE, Brasil. \\ * Autor para correspondência: fholanda@infonet.com.br \\ 3Universidade Federal de Sergipe, Departamento de Química, campus São Cristovão. \\ Av. Marechal Rondon, s/n, CEP 49100-000, São Cristóvão, SE, Brasil. \\ ${ }^{4}$ Universidade Federal do Tocantins, Curso de Engenharia Florestal, campus Gurupi. \\ Rua Badejos, s/n, CEP 77404-970, Gurupi, TO, Brasil.
}

ABSTRACT - The aim of this work was to evaluate the allelopathic effect of extracts of Chrysopogon zizanioides (L.) Roberty and Paspalum millegrana Schrad on germination of lettuce. Aqueous solutions were prepared by maceration and infusion at concentrations of $0,1,3$ and $5 \%$. In the extracts were measured the osmotic potential (OP), concentration of total soluble sugars (CTSS) and electrical conductivity (EC). The effects of the extracts on the germination of the seeds were evaluated by means of the following parameters: first germination count (FGC), germination (G), germination speed index (GSI) and mean germination time (MGT). Even at low concentrations it was possible to identify allelopathic effect, be it inhibiting or accelerating the growth of the seedlings. Low concentrations of the extract caused seed phytotoxicity at the beginning of the germination process. The aqueous extracts of the vetiver grass and paspalum grass showed allelopathic potential.

Keywords: allelopathy, Lactuca sativa L., Paspalum, vetiver

RESUMO - Potencial alopático do Chrysopogon zizanioides e Paspalum millegrana na germinação de alface. Os efeitos alelopáticos são mediados por substâncias pertencentes a diferentes categorias de compostos secundários e podem afetar várias partes da célula. O objetivo deste estudo foi avaliar o efeito alelopático de extratos das espécies Chrysopogon zizanioides (L.) Roberty e Paspalum millegrana Schrad em germinação de alface. Nos extratos foi mensurado o potencial osmótico (PO), concentração de açúcares solúveis totais (AST) e condutividade elétrica (CE). Foram avaliados os efeitos dos extratos sobre a germinação das sementes por meio dos seguintes parâmetros: primeira contagem de germinação (PCG), germinação (G), índice de velocidade de germinação (IVG) e tempo médio de germinação (TMG). Mesmo em baixas concentrações foi possível identificar efeito alelopático, seja ele inibindo ou acelerando o crescimento das plântulas. Baixas concentrações do extrato causaram fitotoxicidade das sementes no início do processo de germinação. Os extratos aquosos do capim vetiver e do capim paspalum evidenciaram potencialidades alelopáticas.

Palavras-Chave: alelopatia, Lactuca sativa L., Paspalum, vetiver

\section{INTRODUCTION}

Allelopathic effects are mediated by substances belonging to different categories of secondary compounds. Recent advances in the chemistry of natural products, by modern methods of extraction, isolation, purification and identification, have greatly contributed to a better understanding of these secondary compounds, which can be grouped in various ways (Gatti et al. 2010). Among the natural products, are the essential oils produced by plants and stored in highly specialized anatomical structures such as glandular trichomes, oil cells, secretory cavities, ducts and laticifers (Buchanan et al. 2015).

Seed germination and initial seedling development are used to evaluate the allelopathic effect, and isolated plant or allelochemical extracts are often used (Hoffmann et al. 2007, Almeida 2014). The substances with allelopathic effects can be flavonoids, phenols, terpenoids, alkaloids, polyacetylenes, fatty acids, peptides and others (Almeida 2016). Flavonoids participate in processes related to ionic absorption that may compromise the electrochemical gradient of the cell membranes of the roots, and depending on the concentration may promote or inhibit roots growth (Lupini et al. 2016).

The vetiver grass (Chrysopogon zizanioides (L.) Roberty), classified in the Poaceae family, is a perennial grass that is present in various climates, especially tropical and subtropical, commonly used in the recovery of degraded areas, especially in erosion control due to the presence of small rhizomes, and thin and matted roots system, that 
can reach great depths, allowing the plant resistance to drought and runoff, permitting them to remain adhered to the soil aggregates (Machado et al. 2015). The paspalum grass (Paspalum millegrana Schrad) perennial species, native, also belonging to the Poaceae family, forming dense clumps it is also being studied with a view to use in the recovery of degraded areas, occurring largely from the USA to Brazil, which is distributed in the North, Northeast and Southeast (Oliveira et al. 2013).

Studies on allelopathic effects are still few in number of species, especially when dealing with situations for the recovery of degraded areas, most probably because they mostly deal with technical works with little scientific character. Therefore, the aim of this work was to evaluate the allelopathic effect of extracts of Chrysopogon zizanioides (L.) Roberty and Paspalum millegrana Schrad on germination of lettuce.

\section{MATERIAL AND METHODS}

For conducting trials that evaluated the allelopathic effects of plant extracts of the species of vetiver and paspalum grasses, were collected parts of the plants in clumps located in the slope of the right bank of the River in the city of Amparo de São Francisco, State of Sergipe, with the coordinates $36^{\circ} 50^{\prime} 25.335^{\prime \prime} \mathrm{W}$ and $10^{\circ} 13^{\prime} 34.081^{\prime \prime}$ $\mathrm{S}$ formed by soil classified as Neossolo Flúvico (Embrapa 2013).

The climate of the sedimentary section of the Lower São Francisco, according to the Köppen classification, is the type "Am" (tropical monsoon climate) with an average annual temperature of $25^{\circ} \mathrm{C}$ and average annual rainfall of $744 \mathrm{~mm} \mathrm{yr}^{-1}$. The annual average rainfall is $744.0 \mathrm{~mm}_{\text {year }}{ }^{-1}$, with variations in rainfall distribution throughout the year, with a rainy season between March and August and a dry period between December and February (Codevasf 2014).

Sampled plants were separated in roots and leaves, being dried in an oven at $40^{\circ} \mathrm{C}$ for 48 hours to obtain constant weight of the dry matter. The dried leaves and roots were ground in a knife mill to obtain the powder. These dry material aqueous solutions were prepared by maceration and infusion at concentrations of $0 \%, 1 \%, 3 \%$ and $5 \%$. Infusion was used boiling distilled water and after 48 hours of extraction, the solutions were filtered and stored in the refrigerator until ready to use. Treatment $0 \%$ with only distilled water was considered as control.

The $\mathrm{pH}$ of the extracts was determined according to the methodology Embrapa (2009). In the extracts was measured electrical conductivity (EC) and determined the osmotic potential (OP) according to the formula: $\mathrm{OP}(\mathrm{Mpa})=-0.36$ x EC $\left(\mathrm{mS} \mathrm{cm}^{-1}\right)$ proposed by Ayers \& Westcot (1976).

From samples were quantified concentration of total soluble sugars (CTSS), which was used the phenol-sulfuric method (Dubois et al. 1956). For the dosage, $50 \mu \mathrm{L}$ of the samples (extracts), $450 \mu \mathrm{L}$ of distilled water, $500 \mu \mathrm{L}$ of $5 \%$ phenol and $2.5 \mathrm{~mL}$ of concentrated sulfuric acid were used. The sugar concentration was measured by atomic absorption spectrophotometer and the absorbance value of the blank (distilled water) was subtracted from the absorbance values obtained for the standard curve and samples. Sugar concentrations were determined through the standard glucose calibration curve.

Using the extracts from paspalum and vetiver, germination tests were performed with lettuce seeds (Lactuca sativa L.) in quadruplicate with 50 seeds per gerbox, 200 seeds per treatment, totaling 100 to 5000 gerboxes seeds analyzed for 25 treatments. The seeds were placed on two germitest paper sheets, moistened with the treatments, in a proportion 2.5 times the weight of the substrate, in gerbox boxes and in a germination chamber, of the BOD type at a constant temperature of $20^{\circ} \mathrm{C}$ with photoperiodic control of $8 \mathrm{~h} \mathrm{Light} \mathrm{and} \mathrm{16h} \mathrm{dark} \mathrm{until} \mathrm{the}$ end of the test. Evaluations were performed daily until the seventh day of the experiment (Brasil 2009). In the experiments, approximately $50 \mathrm{~mL}$ of extract per treatment was required in four replicates.

For the evaluation of extract effects on the germination of seeds, the following parameters were considered: (i) first germination count (FGC), (ii) germination (G), (iii) germination speed index (GSI), and (iv) medium time of germination (MTG). All normal seedlings identified by repetition in each treatment were used and the mean of the replicates were calculated for all evaluated parameters. In these parameters, 10 normal seedlings were used per replicate, 40 per treatment, totaling 1000 seedlings.

The first germination count was performed in conjunction with the germination test. At the fourth day after the implantation of the experiments the percentage of normal seedlings was calculated, using the following formula: $\mathrm{G}(\%)=$ amount of normal seedlings (4th day) / 50 (quantity of seeds per gerbox)

In the evaluation of germination percentage, the number of seeds that produced seedlings classified as normal, obtained under the specified conditions and periods, was observed. Normal seedlings are those that have the essential structures to continue their development until they become a plant. At the seventh day, the experiment was concluded and the final percentage of germination was calculated, as follows: $\mathrm{G}(\%)=$ amount of normal seedlings (7th day) / 50 (quantity of seeds per gerbox)

The germination speed index, which is a tool to evaluate seed vigor, was evaluated by means of the mathematical expression that associates the number of seedlings with their normal constituent parts with the number of days. At the end of the test, with the daily data of the number of normal seedlings and the corresponding number of days, the GSI was calculated using the formula proposed by Maguire (1962): GSI $=(\mathrm{G} 1 / \mathrm{N} 1)+(\mathrm{G} 2 / \mathrm{N} 2)+(\mathrm{G} 3 /$ $\mathrm{N} 3)+\ldots+(\mathrm{Gn} / \mathrm{Nn})$, where: G1, G2, G3,.., Gn = number of seedlings computed in the first, second, third and last count; $\mathrm{N} 1, \mathrm{~N} 2, \mathrm{~N} 3, \ldots, \mathrm{Nn}=$ number of days of sowing to the first, second, third and last count.

The germination test material was used, counting daily the number of germinated seeds after the test installation. 
This index represents the weighted average of the time necessary for the germination, taking as a weighting factor the daily germination, calculated by the equation: $\mathrm{MTG}=$ $(\mathrm{G} 1 \mathrm{~T} 1+\mathrm{G} 2 \mathrm{~T} 2+\ldots \mathrm{GnTn}) /(\mathrm{G} 1+\mathrm{G} 2+\ldots+\mathrm{Gn})$, where: MTG - mean time, in days, required to achieve maximum germination; G1, G2 and $\mathrm{Gn}$ - number of seeds germinated and at times $\mathrm{T} 1, \mathrm{~T} 2$ and $\mathrm{Tn}$, respectively.

The experimental design was completely randomized and the parameters $(\mathrm{pH}$, electrical conductivity, and osmotic potential) were submitted to analysis of variance (Test F), where regressions were adjusted between them. The results were submitted to Variance Analysis (Test F) and the means were compared by the Scott-knott test at 5\% probability for the following variables: (i) first germination count, (ii) germination, (iii) germination speed index, and (iv) medium time of germination.

\section{RESULTS AND DISCUSSION}

The $\mathrm{pH}$ in the aqueous extracts by maceration and infusion increased linearly for the two grasses in the leaves in the various concentrations and decreased linearly for both grasses when originating from the roots (Fig. 1).

In all the concentrations $\mathrm{pH}$ varied for maceration between 5.78 to 6.57 , and the aqueous extracts by infusion ranged from 5.38 to 6.68 . The $\mathrm{pH}$ measurements found by Tur et al. (2012) ranged from 6.3 to 6.8 for extracts
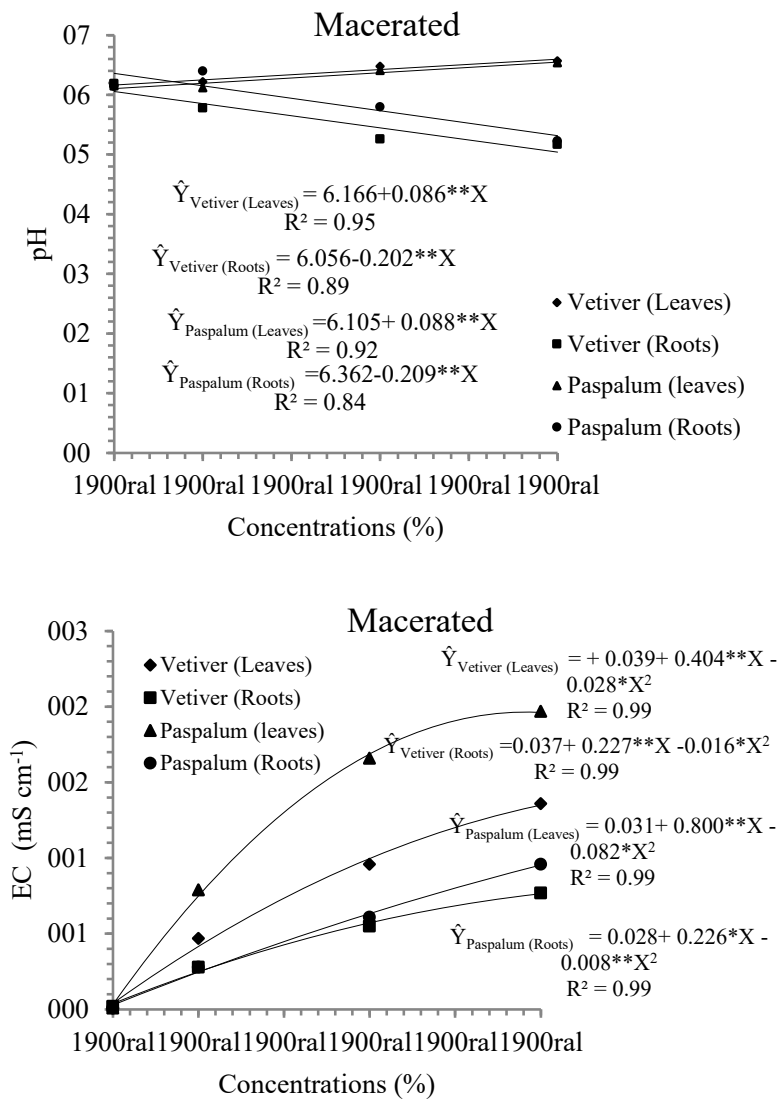

derived from leaf clover (Lonchocarpus campestris (Mart ex Benth)) used for germination of lettuce not differing from the data generated. In working Melhorança Filho et al. (2013) found values close that ranged from 5.56 to 7.07 for extracts of Santa (Cymbopogon citratus (DC) Stapf.) used for the germination of lettuce. According to Carvalho et al. (2016), seedling germination and growth only characterize interference by hydrogenation potential when the medium is very basic or extremely acidic, with harmful effects at $\mathrm{pH}$ below 4 and above 10 being observed.

In relation to EC, a quadratic increase was observed with the increasing concentrations of aqueous extracts, following substantially the same equilibrium trend, but with notable differences between the evaluated species and their respective parts (Fig. 1). EC values ranged from 0.01 to $1.36 \mathrm{mS} \mathrm{cm}^{-1}$ for vetiver macerated leaves, and roots from 0.02 to $0.77 \mathrm{mS} \mathrm{cm}{ }^{-1}$. For the extract of the paspalum, macerated, the values ranged from 0.01 to 1.97 $\mathrm{mS} \mathrm{cm}{ }^{-1}$ for leaves and roots from 0.01 to $0.96 \mathrm{mS} \mathrm{cm}^{-1}$. At infusion, the values ranged from 0.01 to $0.91 \mathrm{mS} \mathrm{cm}^{-1}$ for vetiver leaves, and roots from 0.02 to $0.52 \mathrm{mS} \mathrm{cm}^{-1}$. For the paspalum, EC values for the infused extracts ranged from 0.01 to $0.77 \mathrm{mS} \mathrm{cm}^{-1}$ for leaves and roots from 0.01 to 0.61 $\mathrm{mS} \mathrm{cm}{ }^{-1}$. A trend of higher $\mathrm{EC}$ values for both grasses in leavest extracts may be related to higher concentrations of ions. According to Souza et al. (2006), values EC below $20 \mathrm{mS} \mathrm{cm}-1$ do not negatively influence germination.
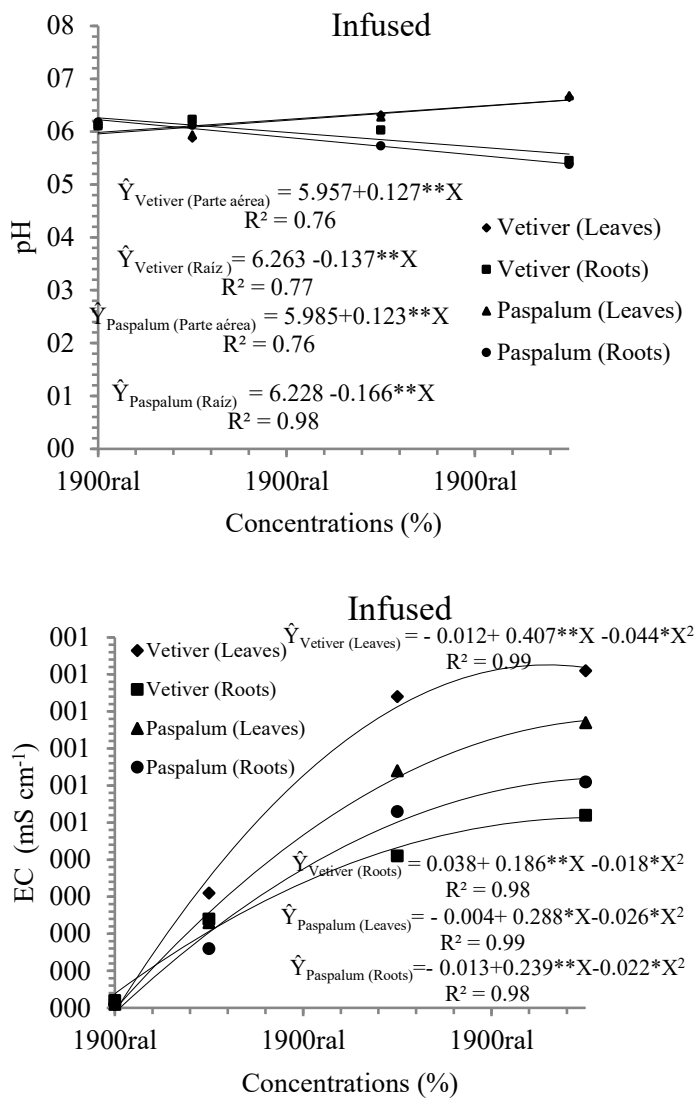

Fig. 1. Adjusted regressions in $\mathrm{pH}$ and $\mathrm{EC}$ of the aqueous extracts of vetiver (Chrysopogon zizanioides) and paspalum (Paspalum millegrana) in leaves and roots parts, as a function of concentrations. Significant at * $\mathrm{p}<0.05, * * \mathrm{p}<0.01$. 
Under stress conditions, osmotic adjustment is the key mechanism by which plants become able to adapt to high salinity levels and continue to obtain sufficient water for growth and development (Schossler et al. 2012).

The values of OP are generally higher in the aqueous extracts for the two grasses leaves with concentration of $5 \%$ (Fig. 2). Values ranged from 0.00 to $-0.44 \mathrm{Mpa}$ for vetiver macerated leaves, and roots from 0.00 to -0.28 Mpa. For the extract of paspalum, macerated, the values ranged from 0.00 to $-0.71 \mathrm{Mpa}$ for shoot and roots from 0.00 to $0.35 \mathrm{Mpa}$. In infusion, values ranged from 0.00 to $-0.33 \mathrm{Mpa}$ for vetiver leaves, and roots from 0.00 to -0.19 Mpa. The paspalum, values ranged from 0.00 to $0.21 \mathrm{Mpa}$ for shoot and roots from 0.00 to $0.22 \mathrm{Mpa}$.

In Figure 2, it is possible to verify that the osmotic potential is inversely proportional to the electrical conductivity. Similar results were found by Coelho et al. (2014) studying different concentrations of sodium chloride solutions $(\mathrm{NaCl})$, potassium chloride $(\mathrm{KCl})$, calcium chloride $\left(\mathrm{CaCl}_{2}\right)$ and sodium sulfate $\left(\mathrm{Na}_{2} \mathrm{SO}_{4}\right)$ in analogy to field conditions.

The values of osmotic potential exhibited low variation between the aqueous extracts of the vetiver and the paspalum, with values of -0.01 to $-0.10 \mathrm{MPa}$ for all extracts. These values are probably outside the extreme values that could affect the germination and development of lettuce seedlings. In the case of seed germination, the values of the osmotic potential do not exceed -0.2 MPa in allelopathic tests, according to Gatti et al. (2007).

In the different concentrations of aqueous extract studied, the total soluble sugars contents increased quadratically for both grasses (Fig. 2). Concentrations of TSS presented higher values for vetiver grass in roots extracts by both maceration and infusion techniques. The opposite was observed for extracts of paspalum grass where higher values for leaves were found both by the technique of maceration and infusion.

Values ranged from 0.00 to $1.91 \mathrm{mg} \mathrm{mL}^{-1}$ for vetiver macerated leaves, and roots from 0.00 to $3.08 \mathrm{mg} \mathrm{mL}^{-1}$. The paspalum, macerated, values ranged from 0.00 to 2.13 $\mathrm{mg} \mathrm{mL} \mathrm{m}^{-1}$ for leaves and roots from 0.00 to $2.28 \mathrm{mg} \mathrm{mL}^{-1}$. In infusion, values ranged from 0.00 to $2.03 \mathrm{mg} \mathrm{mL}^{-1}$ for vetiver leaves, and roots from 0.00 to $3.33 \mathrm{mg} \mathrm{mL}^{-1}$. The paspalum, values ranged from 0.00 to $2.32 \mathrm{mg} \mathrm{mL}^{-1}$ for leaves and root from 0.00 to $2.45 \mathrm{mg} \mathrm{mL}^{-1}$. This similar behavior of the TSS concentration of leaves extracts and paspalum roots were not presented when Melo et al. (2007) presented the species Paspalum paniculatum L., which presented lower concentrations of TSS in the roots than in the leaves.

The ratio of TSS concentration with the OP did not affect the process of seed germination, such as the values of TSS concentrations varied and the concentration is directly proportional to the osmotic potential. Possible

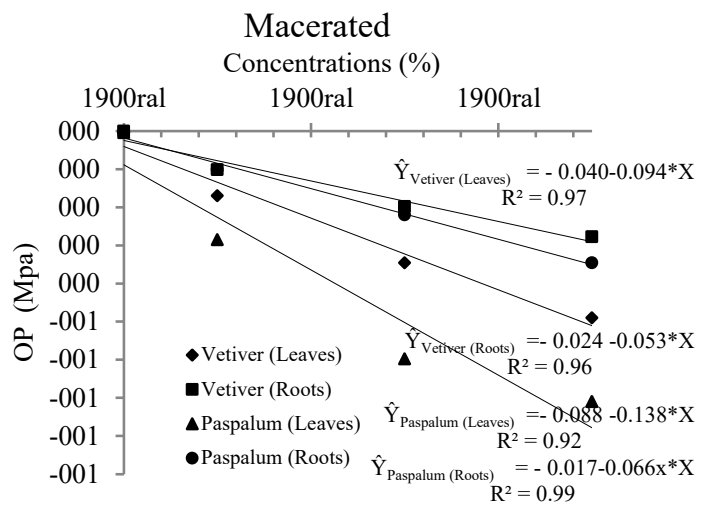

Macerated

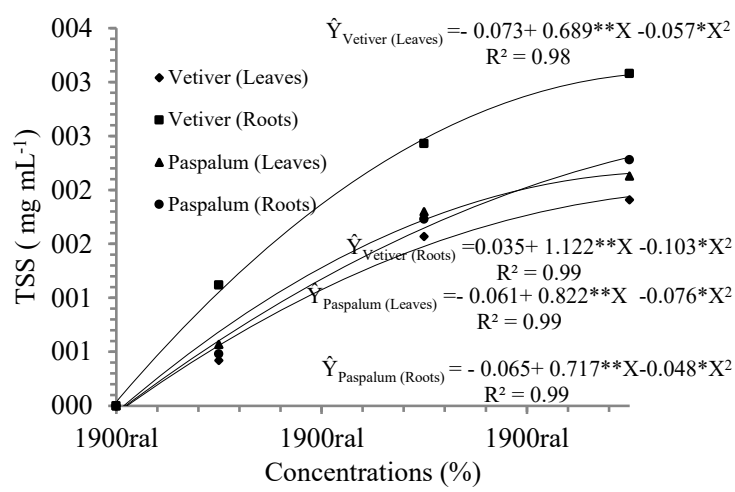

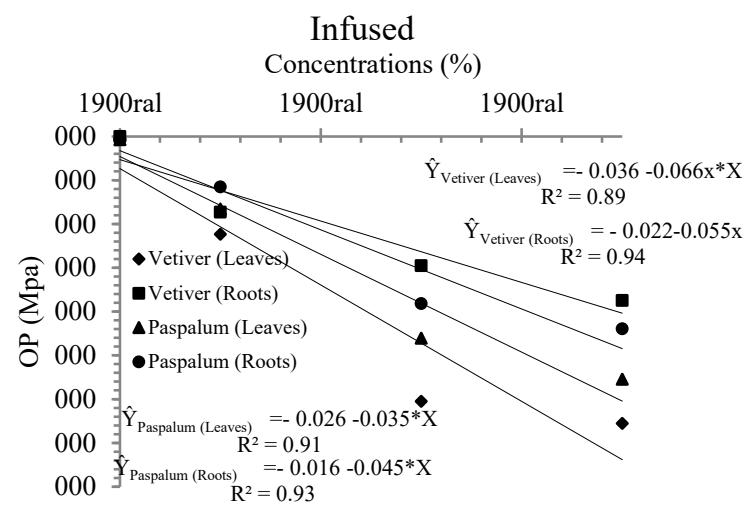

Infused

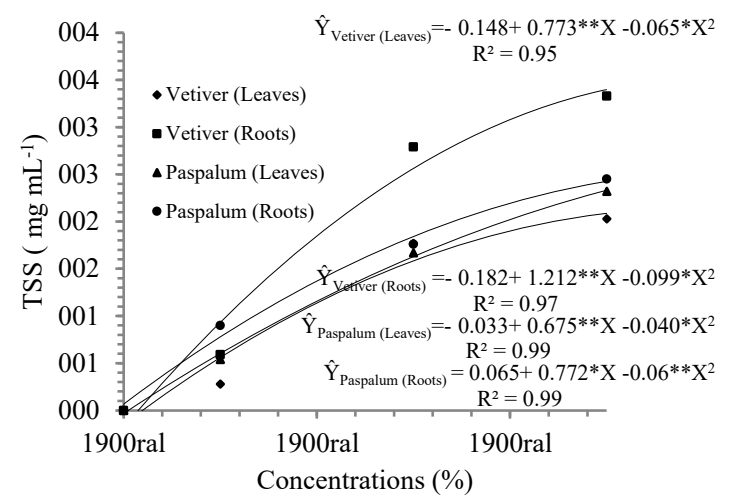

Fig. 2. Adjusted regressions in OP and TSS of aqueous extracts of vetiver (Chrysopogon zizanioides) and paspalum (Paspalum millegrana) in leaves and roots parts, as a function of concentrations. Significant at $* \mathrm{p}<0.05, * * \mathrm{p}<0.01$. 
metabolic adjustments may have occurred and regulated the germination through the osmoregulatory processes (Soares et al. 2015).

According to the data presented in Table 1, it can be inferred that treatments $2,6,7,8,10,11,12,13,14$, $16,17,19,22$ and 25 showed statistically inhibition or acceleration, In relation to the control for the four studied variables, FGC, G, GSI and MTG. The other treatments did not differ significantly from the control, in at least one variable studied. The GSI was the only variable that all the treatments referring to the aqueous extracts presented statistical difference in relation to the control, treatment 1 to the germination tests of lettuce seeds with distilled water only.

The first count test is important because it evaluates the speed of germination, indicating that the higher the germination of the seeds in the first count, the greater its vigor (Nakagawa 1999). There is a great competition between seedlings in clearing habitats, since the individuals that emerge earlier may have a competitive advantage over those that appear late, typical characteristics of the pioneer species (Garwood, 1983).

It is possible to verify in Table 1 a statistical difference in the increase of the percentage of the first germination count (FGC), in relation to the control (treatment 1), in the treatments 2, 3 and 4, referring to the tests performed with the extracts of the leaves of vetiver using the technique of soaking at concentrations of 1,3 and $5 \%$, respectively. In treatment 14 , referring to the test performed with the aqueous extract of the leaves vetiver using the technique of infusion at the concentration of $1 \%$. In the treatments Table 1 there was a statistical difference with a decrease in the percentage of the first germination count and there was no statistical difference in treatments 9 and 24 .

Through the study of germination of lettuce seeds with 25 treatments, it was possible to verify greater seed germination when submitted the extracts by infusion, performed at different concentrations, parts and types of

Table 1. Mean values of the variables FGC, G, IVG and MTG of 25 treatments.

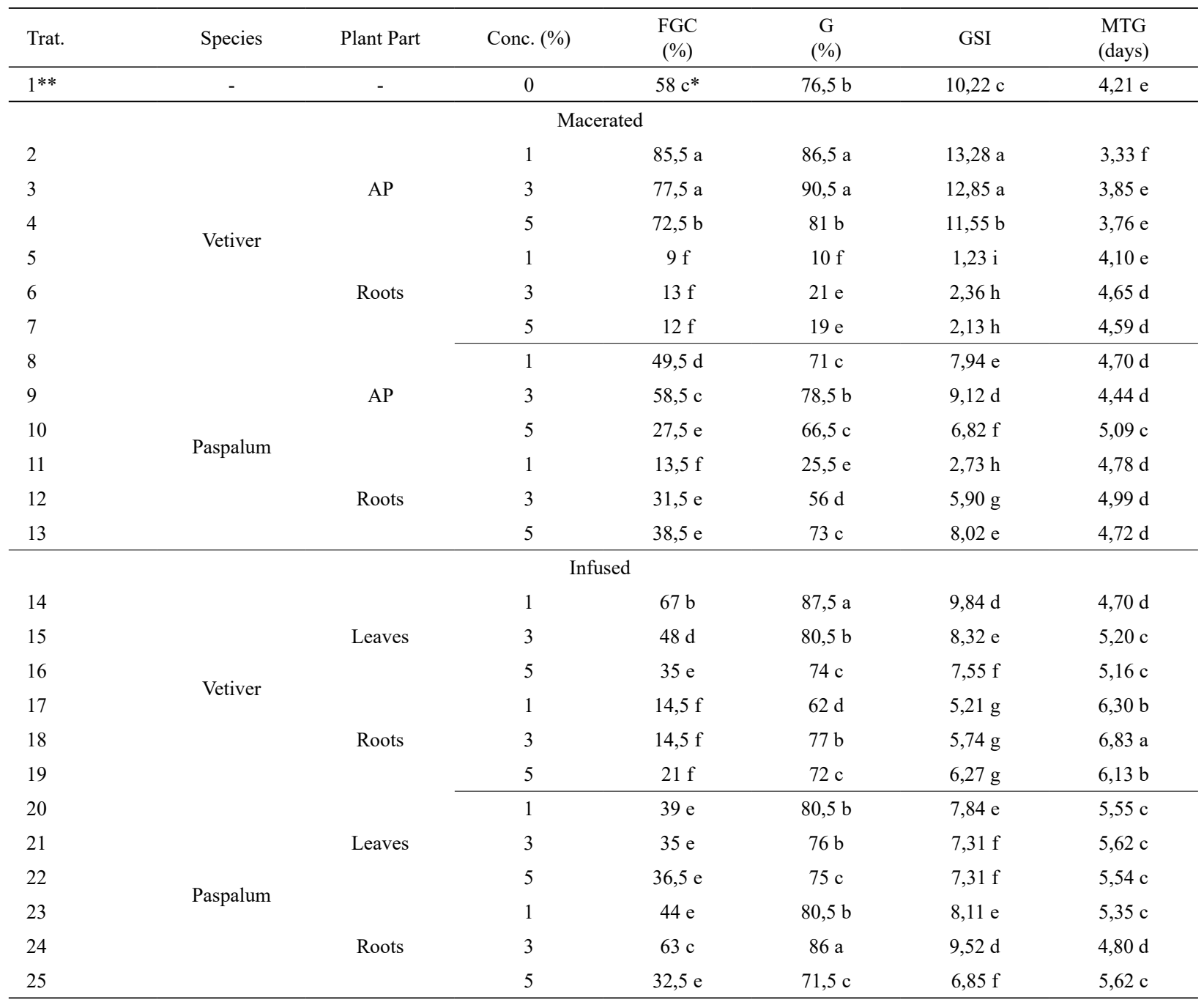

* Means followed by the same letter in the column, do not differ by Scott-Knott test at $5 \%$ probability. ** The treatments correspond to the aqueous extracts by maceration and infusion of the leaves and roots of the vetiver and paspalum species, in three concentrations $0,1,3$ and $5 \%$. Besides the absence of the species for the control, carried out only with distilled water. Trat. - treatment, Conc. - concentrations. 
species compared to the control and maceration for extracts. This same characteristic occurred with the variable time of germination.

In Table 1, there was no statistical difference in 17 treatments compared to the control. Making a comparison with the control treatments had higher percentages 4 and 13 smaller percentage germination treatment.

In a study by Felix (2007) on the allelopathic effect Amburana Cearenses found that it was more effective on seedling development than the germination itself, since even at low concentrations where seeds germinated seedlings had become abnormal, especially the roots system and apparently unable to develop properly.

Even at low concentrations it was possible to identify allelopathic effect, either inhibiting (treatments 5, 8, 11 and 17) or accelerating the growth of seedlings (treatments 2 and 14). This fact evidences that low concentrations of the extract were efficient in causing seed phytotoxicity at the beginning of the germination process.

Inhibitory action and stimulating action on germination were observed by Teixeira \& Bonfim (2014) who obtained similar results when they tested aqueous extracts of different medicinal species. Borella et al. (2009) explain that the effects of allelopathic compounds are related to the physiological processes of the recipient plant and generally act as inhibitors of germination and growth.

The highest GSI values found in germination tests were lettuce $13.28,12.85,11.55$ and 10.22 , treatments $2,3,4$ and 1 , respectively. These treatments correspond to extracts of the leaves of the vetiver in the three concentrations by the maceration technique, with treatment 1 being the control treatment (Table 1).

It was possible to observe that only 4 treatments reached lower germination times (treatments 2, 3, 4, and 5), and the others were higher. Statistically, treatment 2 was the one that obtained the lowest mean germination time, the treatments 6 until 25 obtained higher average germination times and did not present statistical difference with treatments 3, 4 and 5 .

The germination speed is the inverse of the average germination time, so the lowest mean values germination time correspond to the highest germination speed values. According to Fontana et al. (2016), the speed at which seeds germinate after sowing is of great importance for the satisfactory establishment of seedlings in the field. The delay in germination can expose the seeds to unfavorable conditions of temperature, as well as the attack of pests and diseases, causing damages to the performance of the seeds.

\section{REFERENCES}

Almeida, L.F.R., Oliveira Portella, R., Bufalo, J., Marques, M.O.M., Facanali, R. \& Frei, F. 2016. Non-oxygenated sesquiterpenes in the essential oil of Copaifera langsdorffii desf. increase during the day in the dry season. PloS one 11: 1-12.

Almeida, L.F.R., Oliveira Portella, R., Facanali, R., Marques, M.O.M. \& Frei, F. 2014. Dry and wet seasons set the phytochemical profile of the Copaifera langsdorffii Desf. essential oils. Journal of Essential Oil Research 26: 292-300.
Ayers, R.S. \& Westcot, D.W. 1976. Water quality for agriculture. Disponível em: http:// http://www.fao.org Acessado em 10.05.2016.

Borella, J., Wandscheer, A.C.D., Bonatti, L.C. \& Pastorini, L.H. 2009. Efeito alelopático de extratos aquosos de Persea americana Mill. sobre Lactuca sativa L. Revista Brasileira de Biociências 7: 260-265.

Brasil, Ministério da Agricultura, Pecuária e Abastecimento. 2009. Regras para análise de sementes. Editora Mapa, Brasília. 399p.

Buchanan, B.B.; Gruissen, W. \& Jones, R.L. 2015. Biochemistry and molecular biology of plants. American Society of Plant Physiologists, Rockville Maryland. $1367 \mathrm{p}$.

Carvalho, W.P., Teixeira, L.G.V., Neto, D.O.A., Moreira, J.M.S. \& Cunha, C.E. 2016. Alelopatia de resíduos de plantas de cobertura no controle de braquiária cv. Marandu. Revista Brasileira de Biociências 14: 61-68.

Companhia de Desenvolvimento do São Francisco e Vale do Paraíba - Codevasf. 2014. Disponível em: http://www.codevasf.gov.br Acessado em 11.05.2014.

Coelho, J.B., Barros, M.D.F., Bezerra Neto, E. \& Souza, E.D. 2014. Ponto de murcha permanente fisiológico e potencial osmótico de feijão caupi cultivado em solos salinizados. Revista Brasileira de Engenharia Agrícola e Ambiental 18: 708-713.

Dubois, M., Gilles, K.A., Hamilton, J.K., Rebers, P.T. \& Smith, F. 1956. Colorimetric method for determination of sugars and related substances. Analytical chemistry 28: 350-356.

Empresa Brasileira de Pesquisa Agropecuária - Embrapa - 2013. Sistema Brasileiro de Classificação de Solos., Embrapa Solos. Rio de Janeiro. 353p.

Felix, R.A.Z., Ono, E.O., Silva, C.P., Rodrigues, J.D. \& de Pieri, C. 2007. Efeitos alelopáticos da Amburana cearensis L. (Fr. All.) AC Smith na germinação de sementes de alface (Lactuca sativa L.) e de rabanete (Raphanus sativus L.). Revista Brasileira de Biociências 5: 138-140.

Fontana, A., Teixeira, W.G., Balieiro, F.D.C., Moura, T.P.A.D., Menezes, A.R.D. \& Santana, C.I. 2016. Characteristics and attributes of Oxisols under different land uses in the western region of the state of Bahia, Brazil. Pesquisa Agropecuária Brasileira 51: 1457-1465.

Garwood, N.C. 1983. Seed germination in a seasonal tropical forest in Panama: a community study. Ecological Monographs 53: 159-181.

Gatti, A.B., Andrade, S.C.J.G. \& Ferreira, A.G. 2007. Avaliação da Atividade Alelopática de Extratos Aquosos de Folhas de Espécies de Cerrado. Revista Brasileira de Biociências 5: 174-176.

Gatti, A.B., Ferreira, A.G., Arduin, M. \& Perez, S.C.G.D.A. 2010. Allelopathic effects of aqueous extracts of Artistolochia esperanzae O. Kuntze on development of Sesamum indicum L. seedlings. Acta Botanica Brasilica 24: 454-461.

Hoffmann, C.E.F., Neves, L.A.S., Bastos, C.F. \& Luz Wallau, G. 2007. Allelopathic activity of Nerium Oleander L. and Dieffenbachia picta schott in seeds of Lactuca sativa L. and Bidens pilosa $\mathrm{L}$. Revista de Ciências Agroveterinárias (Journal of Agroveterinary Sciences) 6: 11-21.

Lupini, A., Sorgonà, A., Princi, M.P., Sunseri, F. \& Abenavoli, M.R. 2016. Morphological and physiological effects of trans-cinnamic acid and its hydroxylated derivatives on maize root types. Plant Growth Regulation 78: 263-273.

Machado, L., Holanda, F.S.R., Silva, V.S., Maranduba, A.I.A. \& Lino, J.B. 2015. Contribuição do sistema radicular do capim-vetiver para estabilização do talude do Rio São Francisco. Semina: Ciências Agrárias 36: 2453-2464.

Maguire, J.D. 1962. Speed of germination - aid in selection and evaluation for seedling emergence and vigor. Crop science 2: 176-177.

Melhorança Filho, A.L., Araújo, M.L., Silva, J.E.N., Júnior, P.P.O. \& Silva, M.F. 2015. Avaliação do potencial alelopático de capim-santo (Cymbopogon citratus (DC) Stapf. sobre o desenvolvimento inicial de alface (Lactuca sativa L). Ensaios e Ciência: C. Biológicas, Agrárias e da Saúde 16: 21-30.

Melo, H.D., Castro, E.D., Soares, A.M., Melo, L.D. \& Alves, J.D. 2007. Alterações anatômicas e fisiológicas em Setaria anceps Stapf ex Massey e Paspalum paniculatum L. sob condições de déficit hídrico. Hoehnea 34: 145-153.

Nakagawa, J., Krzyzanowski, F.C., Vieira, R.D. \& França Neto, J.D.B. 1999. Testes de vigor baseados no desempenho das plântulas. Vigor 
de sementes: conceitos e testes.: Associação Brasileira de Tecnologia de Sementes, Londrina 1: 9-13.

Oliveira, R.C.D., Santana, S.H.D., Silva, A.S.D., Maciel, J.R. \& Valls, J.F.M. (2013). Paspalum (Poaceae) in Rio Grande do Norte, Brazil. Rodriguésia 64: 847-862.

Schossler, T.R., Machado, D.M., Zuffo, A.M., Andrade, F.R. \& Piauilino, A.C. 2012. Salinidade: efeitos na fisiologia e na nutrição mineral de plantas. Enciclopédia Biosfera 8: 1563-1578.

Soares, M.M, Santos Junior, H.C., Simões, M.G., Pazzin, D. \& Silva, L.J. 2015. Estresse hídrico e salino em sementes de soja classificadas em diferentes tamanhos. Pesquisa Agropecuária Tropical 45: 370-378.
Souza, L.S., Velini, E.D., Martins, D. \& Rosolem, C.A. 2006. Efeito alelopático de capim braquiária (Brachiaria decumbens) sobre o crescimento inicial de sete espécies de plantas cultivadas. Planta Daninha 24: 657-668.

Teixeira, D.A. \& Bonfim, F.P.G. 2014. Efeito alelopático de melissa, capim-cidreira, lavanda e alecrim na germinação e vigor de sementes de alface. Biotemas 27: 37-42.

Tur, C.M., Martinazzo, E.G., Aumonde, T.Z. \& Villela, F.A. 2012. Atividade alelopática de extratos aquosos de folhas de rabo-debugio sobre a germinação e o crescimento inicial de plântulas de alface. Revista Brasileira de Biociências 10: 521-529. 